\title{
Types of Maxim in Moana Movies
}

\author{
Siska Damayanti'), Mhd. Johan ${ }^{2)}$ \\ ${ }^{1}$ Universitas Putera Batam \\ sisdamz@gmail.com \\ ${ }^{2}$ Universitas Putera Batam \\ thorshid@gmail.com \\ Received: $26^{\text {th }}$ June 2021| Revised: 27 ${ }^{\text {th }}$ September 2021| Accepted: 13 December 2021 \\ Email Correspondence: sisdamz@gmail.com
}

\begin{abstract}
Having a conversation is one way to get more information. When the speaker is talking to the listener, they must have context in it so that there is no misunderstanding between the speaker and the listener. To prevent misinterpretation between the speaker and the hearer, Grice proposes using the concept of cooperative values, which consists of a maxim, a simple assumption, and it can be modified. The purpose of this research is to find out the type of maxim found in Moana movie. The researcher used qualitative descriptive to reveal the study, collecting the data and analyzing the data by using Pragmatics identity method. The result found that there are four maxims, namely maxims of quality, quantity, manner, and relevance in conversation of Moana movie. The researcher took 20 data from the script and found 8 maxim of quantity, 3 maxim of quality, 4 maxim of relation, and 5 maxim of manner in the script. It can be concluded that Moana did all cooperative principle in her utterances, but mostly, Moana used quantity maxim. It can be concluded that submissive of cooperative principle are mostly obeyed by character in Moana movie, so the result of communication is effective as required.
\end{abstract}

Keywords: maxim, pragmatics, movie

\section{INTRODUCTION}

Language is a form of communication that is very significant in human life because it allows people to interact with one another. Language is used to convey a message or to express what people believe. There are two types of communications texts based on linguistics: Trudgill (2000) mentioned that they are spoken text and written text. Spoken text means that it is delivered directly, while written text means that it is delivered by some tools and process to show the message, for example the writer and the interpretation.

Speaking is one way that humans use as a tool to convey messages and communicate between others. Having a conversation is one way to get more information. When the speaker is talking to the listener, they must have context in it so that there is no misunderstanding between the speaker and the

Online at https://journal.universitasbumigora.ac.id/index.php/humanitatis/

DOI $\quad$ : https://doi.org/10.30812/humanitatis.v8i1.1310 
listener (Mugheri, 2018). One way to avoid misunderstandings is that an interaction can be built when the two speakers and listeners have the principle of cooperation in conducting a conversation. Cooperative means that the speaker knows in every speech the speaker says. The cooperative principle provides a way to carry out cooperative conversations by pointing meaning to the conversation. Birner (2012) said that cooperative principle argued that people must fulfill a number of rules which are referred to as conversational maxims or called Gricean maxims.

In order to communicate through conversation successfully, two or more people as conversation participants must be cooperative so that there is no misunderstanding in the conversation. The speaker can get the message from the hearer directly in the conversation clearly and the listener can understand the meaning, even the hidden meaning, in the speaker's speech. Grice in (Yule, 2010) states that people did conversations if they fulfill the Cooperative Principles outlined in four sub-principles or principles. Birner (2012) classified maxims become four. The four maxims are the maxim of quantity, quality, relevance, and manner. These principles make conversation run smoothly and effectively to achieve its goals.

There are some writers that has similar studies based on the maxim analyzing. The first is The Violation and Flouting of Cooperative Principles in the Ellen Talk Show by (Zebua, 2017). The researcher discovers the types of principles used in dialogue, and how the principles of cooperation are violated in film conversations that violate principles. The second research The Gricean Cooperative Principle: Flouting and Hedging in the Conversations in Joseph Conrad's The Secret Agent by (Yuliasri, 2014). The research focused on the flouting and hedging the conversational maxims that had been done by the characters in the conversations in Joseph Conrad's The Secret Agent.

In this study, it is important to analyze because in every conversation, the possibility of misunderstanding occurs almost every day. And the maxim of conversation is important to achieve communicative conversation with cooperative principle methods. (Siregar, 2016) said that there will also be a number of explanations to berate the proverb such as avoid hurting the listener's feelings, lies when avoiding unpleasant situations such as punishment or being forced to study for the rest of the day.

Within this theory, the researcher found 4 types of maxim: (1) Maxim of Quantity, which instructs speakers to make their contribution as informative as necessary, but not more informative than necessary; (2) Maxim of Quality, which teaches speakers to make their contribution true, not to say anything they think to be incorrect or for which they lack evidence. (3) Maxim of relation, which instructs speakers to be relevant.; and (4) Maxim of Manner, which tells speakers to be perspicuous: to eliminate ambiguity in speech, to keep things simple (avoid unnecessary prolixity), and to keep things in order.

Online at https://journal.universitasbumigora.ac.id/index.php/humanitatis/

DOI : https://doi.org/10.30812/humanitatis.v8i1.1310 
Maxim of relevance requires speaker contributions that are relevant to the speaker's question. Example of the maxim of relevance:

A: What do you bring today?

B: I bring the novel. (Greenall, 2006)

From the example, the condition happened when speaker A asked what speaker B brought and then the speaker B answer questions according to what was asked not too much or less. Example of flouting a maxim:

A: What do you bring today?

B: I love the novel. (Vergis, 2017)

The situation when speaker A asked what B brought, but speaker B flouted or disobeying this maxim of quantity. Speaker B does not answer the question based to what was asked but speaker B knew that A brought Novel because speaker B loves it.

Afterwards, the maxim can be found some stories, especially in the interaction with conversation directly in movie or novel. The researcher is interested to find the types of maxim in the script film which the title Moana by Ron Clements, John Musker, Pamela Ribon, and Taika Waititi.

One of the conversations is between Moana and Maui

Maui : What are you doing?

Moana : Finding you better way in.

Maui : We won't make it

Moana : We will.

From the conversation above it is one of the data maxim of manner. It can be seen when Moana is giving information or answering clearly not ambiguity. It is proven from the utterance of the Moana, she does not speak ambiguity just to the point without adding the other information.

Based on cases and data found the type of proverb in the film itself and also the saying that violates the proverb, and the most dominant saying used appears in the film "Moana." So the researcher is interested in taking this topic to learn more and tell people about the importance of the principle of cooperation. The researcher hopes that this will be a leader to have good communication and also be able to determine the type of saying itself.

In communication, as a human being needs to talk one to another. Understanding what the speaker's utterance is the important because sometimes, not all the utterance can be understood or it must be implied meaning and cannot be predicted so the people must know about the context first. According to Yule (2010) pragmatics is the study of meaning It studies the utterance of a speaker in a conversation,

Online at https://journal.universitasbumigora.ac.id/index.php/humanitatis/

DOI : https://doi.org/10.30812/humanitatis.v8i1.1310 
meaning that interpreted by the listener. It also includes context or the circumstances when the conversation occurs in the analysis. In communication, as a human being needs to talk one to another. Understand what the speaker's utterance is the important because sometimes, not all the utterance can be understood or it must be implied meaning and cannot be predicted so the people must know about the context first. Because of that, pragmatics describes as a study of meaning in a context.

An utterance is not only has explicit meaning but also implicit meaning. The implicit meaning can be known from the actions taken by someone when he speaks. Because of that, there comes the theory of speech acts. According to Tutuarima (2019) Speech act involves an important notion in pragmatics known as language use in context, which takes into consideration the speaker's and addressee's verbal and nonverbal contributions to the meaning negotiation in interaction. Because pragmatics is the study of language in use, its scope is significantly large.

The cooperative principle ensures that your conversational contribution is as necessary by the agreed-upon purpose or direction of the conversation exchange in which you are participating at the time it occurs. It can be said that Cooperative Principle is explaining about the speaker and the hearer. The speaker has to speak clearly, easy to understand and the hearer get what the speaker want or mean (Cummings, 2009).

The hearer can understand what the speaker means or wants by looking at the speaker action or other. Cooperative principle has 4 kinds of maxim there are maxim Quantity, Quality, maxim of relation and maxim Manner.

According to (Birner, 2012) to make a contribution as information as is required for the current purpose of the exchange and do not make your contribution more information than is required. It means that Quantity is the speaker only gives information about what the hearer needs not to give too much information and also less information.

For example:

Fandi : How many people are flying with you today?

Intan : There are three of us, my father, my mother and I (Utami, 2019).

This conversation happened when Fandi was in the airport and he asked Intan how many people that going flight. This conversation expressed maxims of quantity because Intan gives right and not give too much or less information about how many people are flying with her.

Maxim Quality is about a fact, it ask the speaker to tell something which true not false. For example:

Ichal : do you know where Eiffel tower?

Nia $\quad$ : it's in Paris

Online at https://journal.universitasbumigora.ac.id/index.php/humanitatis/

DOI : https://doi.org/10.30812/humanitatis.v8i1.1310 
The conversation above is part of maxim Quality because Nia answers truly that Eiffel tower is in Paris.

This maxim focused on the relevant from the answer person on another hand the contribution should be relevant with the conversation. For example:

Ann : What time is it?

George : Our lecture has begun the class (Lestari, 2019)

It has no connection with the question which the answer must be time but when the answerer say that "Our lecture has begun the class" it has relevant because when the questioner ask "what time is it?" it the situation when they are on the way to class room.

Maxim of manner focused on how people answered the ways they talked and speak to the hearer. To know more about this maxim, there are some characteristics of maxim manner, they are:

1. Avoid obscurity of expression

2. Avoid ambiguity

3. Be brief

4. Be ordered

Maxim of manner asks the speaker for not telling something not ambiguity and no too much explanation for example.

Fadil: $\quad$ What are you doing here?

Ina: $\quad$ I want to take my mathematic book

This conversation is maxim of manner which Ina is answering Fadil question clearly.

\section{RESEARCH METHOD}

In doing this research, the researcher collected the data by wacthing Moana's movie and classifying it based on the theory used by Grice. This research used qualitative research to analyze the assumptions identified in the social media twitter. For this study, the method that used is descriptive qualitative research method. This researcher revealed to analyze the type of maxim in the movie "Moana" so from the data, they were taken in the dialogue "Moana". In process of collecting data, the researcher used observational method by(Sudaryanto,2015). He states that observational method is a method of collecting data by observing the data. In this research, the researcher used non participatory technique to collect the data because the researcher did not involve in the making of movie. The researcher did not join or play action in the movie and did not have any contribution of making this movie. For analyzing the data researcher used the theory of (Sudaryanto, 2015). There are some procedure the researcher used when analyze the data, they are:

Online at https://journal.universitasbumigora.ac.id/index.php/humanitatis/

DOI : https://doi.org/10.30812/humanitatis.v8i1.1310 
1. The data were identified and classified based on the types of maxim

2. Theory of Grice is applied for the type of presupposition.

3. The data were described based on those theories to answer the research question.

4. The finding was made.

Finally, the researcher presented the result analysis by using informal method to present the analyzed data by using words. The researcher used this method because to make the readers easy to understand.

\section{FINDINGS AND DISCUSSION}

In analyzing data type of maxims, movie "Moana" is used as a data source. The following is the findings and discussion using the data obtained for the types of maxim in the movie "Moana".

\section{Maxim quantity}

\section{Data 1:}

This conversation between Moana and the man who is one of society in the village.

Moana : you're doing great

Man : is it done yet?

Moana : so close

The conversation happened in when someone makes tattoo in the man body and the man felt seek and ask Moana. The conversation can be seen from Moana's utterance "so close" that reflected maxim of quantity because Moana answered what the man needed and not give more or less information related to the question.

\section{Data 2:}

The conversation takes place in near the beach when Moana asked her grandmother.

Grandmother : well, then head on back put the stone at there

Moana : why you trying to talk me all of it?

Grandmother : you said that's what you want

Moana $\quad:$ it is.

This conversation happened when grandmother asked Moana to put back the stone near the beach. This is one of the data consist of maxim quantity, grandmother is telling what Moana needs. By using this sentence "You said that's what you want", it can be categorized as maxim of quantity. Because Moana answered based on what grandmother asked.

\section{Data 3:}

Online at https://journal.universitasbumigora.ac.id/index.php/humanitatis/

DOI $\quad$ : https://doi.org/10.30812/humanitatis.v8i1.1310 
Moana and Maui do conversation when they are on the boats, (43:56 duration)

Moana : What is your problem? Are you afraid of it?

Maui : No. I'm not afraid

This conversation happened when Moana asked Maui why Maui did not want to help her to fix the stone. Maui gives the answer based on Moana Question and it not too much and not less. It can be seen from the sentence "No. I'm not afraid." So it can be categorized as maxim of quantity.

Data 4:

Villager : Is it done yet?

Moana : So close.

This conversation happened when Villager asked Moana whether it was done or not hunting in the forest and Moana answered "so close." Moana answered with an appropriate answer. It is not too much or less. It can be classified as maxim of quantity.

\section{Data 5:}

\section{Maui : It was Moana, right?}

Moana : Yes. And you will restore the heart!

The conversation happened when Maui did not believe that Moana still alive. When Maui asked Moana, Moana answered with the simple answer by saying "yes" Moana answered it not too much or less so it can be classified as maxim of quantity.

\section{Data 6:}

Villager 1 : What are you going to do?

Tui : We will dig new fields.

The conversation happened when Villagers asked what they are going to do. They did not believe that Moana could save the village. When Villager 1 asked Tui, Tui answered with the simple answer by saying "we will dig new fields" Tui answered it not too much or less so it can be classified as maxim of quantity.

\section{Data 7:}

Moana : And there's a whole ocean. What make us safe?

Tui : We have one rule.

The conversation happened when Moana asked what make us safe. Tui answer it with a simple answer by saying "we have one rule". When Tui answer it, Tui gave with the simple answer that it was not too much or less so it can be classified as maxim of quantity.

Online at https://journal.universitasbumigora.ac.id/index.php/humanitatis/

DOI : https://doi.org/10.30812/humanitatis.v8i1.1310 


\section{Data 8:}

Moana : And he lives up there?

Maui : No, no, no.

The conversation happened when Moana asked what make us safe. Maui answer it with a simple answer by saying "no no no". When Maui answer it, Maui gave with the simple answer that it was not too much or less so it can be classified as maxim of quantity.

\section{Maxim of quality}

\section{Data 9:}

This conversation between Moana and her father when Moana was child happened in (07:17).

Father : Moana, What are you doing? You scared me

Moana : Fun, I want to go back.

Father $\quad$ : I know, I know but you don't go out there it dangerous

This conversation happened when her father saw Moana going out, her father was scared if Moana went to the sea because there was something happened in the sea. This is one of maxim quality. It can be seen when her father is giving true information "dangerous: all people know that if child play around alone in the beach it's dangerous.

\section{Data 10:}

Conversation between Maui and Moana. (01:08:32)

Moana : I have no idea why the ocean choose me, you're but my island is dying so I'm here it just me and you and I want to help

Maui : I have human parents they took one look and decided they did not want me they threw me under the sea.

The conversation happened when Moana cannot believe that ocean chose her to help the stone of Te Fiti. It can be seen from the movie that what Moana said that's true her island is dying because of the stolen of the Fiti heart and Maui also tell something true that he's a human but his parent did not want him.

\section{Data 11:}

Moana : What if we fish beyond the reef?

Tui : No one goes beyond the reef. 
The conversation happened when Moana asked what if they go fishing beyond the reef. And Tui answered it clearly without any confused. Tui with no hesitancy said that "there was nothing in the reef" I can be classified as maxim of quality.

\section{Maxim of relation}

\section{Data 12:}

This conversation happened in 12:37 when grandfather asked moana suggestion.

Grandfather: I'm interested in learning more about the chicken who ate the rock. I mean, he seems to enjoy them, which indicates that he is intelligent. We could probably just cook him because he has pretty much everything.

Moana : Sometimes our strage like beneath this. Far beneath, in some cases but I'm sure this more that Hei-hei than misdia.

The situation happened when her father explained what happened in their village. It was strange but she has to be ready to take care of this village one day. This is one of maxim of relation, it can be seen when Moana answers that question it can be seen that it has not connection with the question but even though it relevant with the question and grandfather understands that Moana does not want the chicken to be cooked.

\section{Data 13:}

The conversation between Moana and her grandma in the beach when Moana have just got incident.

Grandma : whatever just happened Blame it on the pig

Moana : Grandma. Are you gonna help dad?

Grandma : I really miss mom. I don't have to tell him anything.

Moana : he was right about going out there.

This conversation happened when grandma told Moana what happened to their village why her father asked her not to go out and this can be categorized as maxim of relation, grandmother gives a relevant answer by saying this sentence "he was right about going out there."

\section{Data 14:}

Maui is trying to give information about lava monster to Moana.

Maui : Ever defeat lava monster?

Moana : No. Have you?

Maui : I'm not going on a suicide mission with some mortal, you can restore the heart without me.

Online at https://journal.universitasbumigora.ac.id/index.php/humanitatis/

DOI : https://doi.org/10.30812/humanitatis.v8i1.1310 
This conversation happened when Maui asked Moana that whether she had defeated monster or not. Maui is giving information which has not connected with Moana question but it has relevant, Maui is try to explain that lava monster is frighten.and he did not want to take a risk of letting Moana with him.

\section{Data 15:}

Moana : What's in there?

Grandma : The answer to the question you keep asking yourself. Who are you meant to be? Go inside, bang the drum, and find out.

The conversation happened when Grandma showed something in the cave and Moana asked herself what was happened. Grandma asked Moana to find out by herself. This conversation can be called as maxim of relation because Grandma gives the relevant answer.

\section{Maxim of manner}

\section{Data 16:}

The conversation happened when the fisherman tells to Moana and her father the problem about fishing and gets nothing at all.

Fisher : our traps in east lagoon, they pulling out less and least fish.

Moana : then we'll rooted the fishing ground

Fisher : we have but there's no fish.

The conversation happened when Moana wanted to fish and fisher said that there was not fish because of Te' Fiti was still angry with someone who stolen her stone. The conversation is one of maxim manner when the fisher say "we have but there's no fish" it can be analyzed that he tells something no ambiguity, not too much and clearly.

\section{Data 17:}

Moana : How do you get your tattoos?

Maui : They show up. When I earn them.

The conversation happened when Moana asked Maui where he found the tattoos and Maui asked that the tattoos showed up by itself. The conversation consist of maxim manner because Maui answered it which tells something and describe why he could get the tattoos.

\section{Data 18:}

Maui : What about the heart?

Moana : He can have it. I've got a better one.

Online at https://journal.universitasbumigora.ac.id/index.php/humanitatis/

DOI $\quad$ : https://doi.org/10.30812/humanitatis.v8i1.1310 
The conversation happened when Maui asked about what about the heart and Moana answered it with briefly to the point and be ordered "He can have it. I've got a better one" The conversation consist of maxim manner because Moana answered it which tells something and not ambiguity.

\section{Data 19:}

Moana : Just tell me what it is.

Maui : I said back off.

The conversation happened when Maui asked Moana to stop and back off because it was dangerous of defeating the monster. The conversation consist of maxim manner as seen "I said back off." As it is known that maxim of manner happened when the speaker wanted to be order and avoid ambiguity.

\section{Data 20:}

The conversation happened when Moana wanted to help the villagers fishing.

Moana : So can we do hunting some animals?

Villager: There's no animal.

The situation happened when Moana was still curious and asked the villagers how about animal. Villagers shows that she was sure that there was no animal there. So, the statement above fulfills the maxim of manner because it was brief and not ambiguous.

An analysis in this study is done by applying two theories which are concerned about the conflict and the psychological aspect of the main character. The theories used are theory of conflict by Kenney (1966) that focused on the internal and external conflict experienced by Valery Legasov as the main character, and followed by theory of psychoanalysis by Freud (1923) that focused on analyzing the mind and behavior the main character possessed. Based on the theory of psychoanalysis, the three parts of human personality that are divided into the id, ego, and superego are analyzed to get the idea which psychological aspect he used in handling conflicts he experienced in the story.

\section{CONCLUSION}

After analyzing in chapter 2 the researcher can conclude that each conversation must have understanding between the speaker and the listener, so that it does not become a misunderstanding. In communication there is a study of meaning or also called pragmatics. To interpret a speech we can find it in conversations, novels, and even films. The researcher carried out his analysis in a film script entitled "Moana". In conducting this analysis the researcher took 20 data from the script and found 8 maxim of quantity, 3 maxim of quality, 4 maxim of relation, and 5 maxim of manner in the script.

Online at https://journal.universitasbumigora.ac.id/index.php/humanitatis/

DOI : https://doi.org/10.30812/humanitatis.v8i1.1310 


\section{REFERENCES}

Birner, B. J. (2012). Introduction to pragmatics (1st ed.). Wiley-Blackwell.

Cummings, L. (2009). Clinical pragmatics (1st ed.). Cambridge University Press.

Greenall, A. K. (2006). Maxims and flouting. Encyclopedia of Language \& Linguistics, 545-548. https://doi.org/10.1016/B0-08-044854-2/00361-8

Lestari, N. G. (2019). An analysis of flouting maxims in conversation speaking of the main character in the movie of home alone 2 "Lost in New York" by John Hughes. Jurnal Joepallt (Journal of English Pedagogy, Linguistics, Literature, and Teaching), 7(1). https://doi.org/10.35194/jj.v7i1.537

Mugheri, N. A., Ayaz, P., Qureshi, A., \& Mugheri, R. A. (2018). The Importance of Pragmatics in English Language Teaching. 18(49042), 112-125.

Siregar, N. (2016). An Analysis of Maxim In The Last Song Movie. The Episteme Journal of Linguistics and Literature, 2(3).

Sudaryanto. (2015). Method dan teknik analysis bahasa. Duta Wacana University Press. https://doi.org/10.1017/CBO9780511757754

Trudgill, P. (2000). Sociolinguistics: An introduction to language and society. In Penguin Books. Pelican books. https://doi.org/10.2307/326846

Tutuarima, Z., Nuraeningsih, N., \& Rusiana, R. (2019). An Analysis of Speech Act Used in London Has Fallen Movie. Vision: Journal for Language and Foreign Language Learning, 7(2), 140. https://doi.org/10.21580/vjv7i23022

Utami, H. (2019). A Study of Politeness Strategies and Flouting of Maxim Used in The Dead Poets Society 1989 Movie. International Journal for Innovation Education and Research, 7(1), 215-228. https://doi.org/10.31686/ijier.vol7.iss1.1306

Vergis, N. (2017). The interaction of the Maxim of Quality and face concerns: An experimental approach using the vignette technique. Journal of Pragmatics, 118, 38-50. https://doi.org/10.1016/j.pragma.2017.07.009

Yule, G. (2010a). The study of language. Cambridge University Press.

Yule, G. (2010b). The study of language (4th ed.). Cambridge University Press.

Yuliasri, I. (2014). The shift of Grice's maxim flouting in Indonesian translation of the Donald Duck comics. Arab World English Journal, 3, 225-238. http://proxy.libraries.smu.edu/login?url=http://search.ebscohost.com/login.aspx?direct=true \&db=eu e\&AN=97342850\&site $=$ ehost-live $\&$ scope $=$ site

Zebua, E. (2017). The violation and flouting of cooperative principles in the Ellen Degeneres Talk Show. Language Circle - Journal of Language and Literature, 12(1), 103-113. https://doi.org/10.15294/lc.v12i1.11474

Online at https://journal.universitasbumigora.ac.id/index.php/humanitatis/

DOI : https://doi.org/10.30812/humanitatis.v8i1.1310 